\title{
POLA PENGGUNA JALAN PADA JALUR PEDESTRIAN SEPANJANG KORIDOR JALAN EMBONG MALANG SURABAYA
}

\author{
Dinda Oktaviani Syafi'i \\ Universitas Pembangunan Nasional \\ "Veteran" Jawa Timur \\ e-mail: dindaoktavianisyafii@gmail.com
}

Febriska Alya Putri Pambagus

Universitas Pembangunan Nasional

"Veteran" Jawa Timur

e-mail: putripambagus@gmail.com

\section{Auriellia Laksmi Kartika}

Universitas Pembangunan Nasional

"Veteran" Jawa Timur

e-mail: auriellialk@gmail.com

\begin{abstract}
ABSTRAK
Koridor pedestrian Jl. Embong Malang Surabaya merupakan salah jalur pedestrian di kawasan Surabaya. Pedestrian sendiri berfungsi memfasilitasi pejalan kaki agar tercipta rasa aman dan nyaman saat melintasi jalan raya atau pergi dari satu tempat dalam jarak tertentu dengan menggunakan moda jalan kaki. Pedestrian Embong Malang sendiri dibagi menjadi dua berdasarkan posisinya yaitu pedestrian utara dan selatan. Adanya perbedaan fasilitas dan lingkungan antar kedua pedestrian ini mengakibatkan adanya perbedaan tingkat pengguna aktivitas pedestrian itu sendiri. Tujuan penelitian ini untuk membahas fasilitas, tingkat aktivitas dan faktor yang mempengaruhi perbedaan tingkat aktivitas koridor pedestrian Jl. Embong Malang. Jenis metode penelitian yang digunakan adalah deskriptif kualitatif dengan pengambilan data melalui observasi menggunakan teknik pengamatan Person Centered Maps Dan Place Centered Maps. Hasil penelitian menunjukkan bahwa fasilitas pedestrian sisi selatan lebih lengkap, sehingga tingkat penggunaan aktivitas lebih tinggi, terutama pada saat libur dengan jalur menuju pusat pebelanjaan. Terdapat 3 faktor yang mempengaruhi tingkat penggunaan pedestrian, yaitu: waktu penggunaan pedestrian, kondisi lingkungan di area pedestrian, dan dimensi serta ketersediaan fasilitas pedestrian.
\end{abstract}

KATA KUNCI: koridor pedestrian, fasilitas, tingkat aktivitas

\section{PENDAHULUAN}

Elemen perancangan kota menjadi hal penting dalam setiap proses rancangan kota, salah satunya adalah fasilitas pedestrian jalan. Pedestrian merupakan wadah untuk menampung kebutuhan masyarakat akan ruang untuk berjalan kaki. Pedestrian harus dapat memberikan keamanan dan kenyamanan bagi penggunanya. Pedestrian menjadi salah satu elemen perancangan kawasan yang menentukan keberhasilan suatu rancangan kawasan kota.

Pedestrian atau umum dikenal dengan trotoar, akan muncul di sekitar fasilitas umum yang memiliki tingkat kepadatan aktivitas yang tinggi seperti di pusat kota. Perkotaan memiliki fasilitas publik seperti pasar, pertokoan sebagai pusat perekonomian, maupun adanya pusat hiburan dan rekreasi. Perkotaan memiliki pula kepadatan penduduk yang tinggi. Surabaya adalah kota metropolis kedua setelah Jakarta. Untuk memfasilitasi kebutuhan mobilitas masyarakat yang tinggi, kota Surabaya gencar melakukan pembangunan fasilitas publik yang tentu berdampak pada adanya potensi pejalan kaki.

Pembangunan pedestrian di kota Surabaya mencakup ruas-ruas jalan utama. Menurut Peraturan Pemerintah Nomor 34 Tahun 2006 tentang Jalan, berdasarkan sifat dan pergerakan pada lalu lintas dan angkutan jalan dibedakan atas Arteri Primer dan Sekunder, Kolektor Primer dan Sekunder, Lokal Primer dan Sekunder, dan Lingkungan Primer dan Sekunder. Jalan Arteri Primer berfungsi menghubungan antar pusat kegiatan nasional dengan kegiatan wilayah. Contoh Jalan Arteri Primer di kota Surabaya adalah Jl. A.Yani, Jl. Wonokromo, dan Jl. Gubeng. Jalan Arteri Sekunder berfungsi menghubungkan kawasan primer dengan kawasan sekunder. Contoh Jalan Arteri Sekunder adalah JI. Embong Malang, Jl. Basuki Rahmat dan Jl. Blauran. Jalan Kolektor Primer berfungsi menghubungkan antar pusat kegiatan nasional dengan lokal atau wilayah dengan kegiatan lokal. Contoh Jalan Kolektor Primer adalah Jl. Gunungsari, Jl. Menganti, dan Jl. Mastrip. Jalan Kolektor Sekunder berfungsi menghubungkan antar kawasan sekunder dua dengan sekunder dibawahnya. Contoh Jalan Kolektor Sekunder adalah JI. Tidar, JI. Kedungdoro, dan Jl. Pemuda. Jalan Lokal Primer berfungsi untuk menghubungkan antar pusat kegiatan nasional dengan lingkungan, wilayah dengan lingkungan, atau lokal dengan lingkungan. Jalan Lokal Sekunder berfungsi menghubungkan antar kawasan sekunder sampai ke perumahan. Jalan Lingkungan Primer berfungsi menghubungkan antar pusat kegiatan di dalam kawasan perdesaan. Jalan Lingkungan Sekunder 
berfungsi menghubungkan antarpersil dalam kawasan perkotaan.

Jalan Embong Malang di Surabaya termasuk dalam kategori jalan Arteri Sekunder yang mengubungkan Jalan Arteri Sekunder Jl. Basuki Rahmat menuju Jalan Arteri Sekunder Jl. Blauran dan Jalan Kolektor Sekunder JI. Tidar dan JI. Kedungdoro. Jalan Embong Malang merupakan salah satu jalan strategis di tengah kota Surabaya. Jalan ini strategis sebab di kanan-kiri jalan berjejer bangunan komersial di sepanjang jalan seperti Mall Tunjungan Plaza, hotel, dan pusat perdagangan barang dan jasa lainnya.

Jalan Embong Malang difasilitasi dua pedestrian yaitu pedestrian bagian Utara dan Selatan. Keduanya memiliki perbedaan elemen pelengkap pedestrian, sehingga dalam amatan sepintas mengakibatkan terjadi perbedaan kuantitas pengguna dikedua pedestrian tersebut. Berdasarkan hal tersebut maka sangat menarik untuk dikaji lebih dalam terkait perilaku manusia di pedestrian Jalan Embong Malang ini: bagaimanakah pola perilaku pengguna jalan pada jalur pedestrian sepanjang koridor Jalan Embong Malang Surabaya. Berdasarkan permasalahan tersebut, maka tujuan penelitian ini adalah untuk mengidentifikasi fasilitas jalur pedestrian, untuk mengetahui tingkat pengguna koridor pedestrian dan untuk mengidentifikasi factor yang mempengaruhi ketimpangan jalur pedestrian Jalan Embong Malang Surabaya.

\section{TINJAUAN PUSTAKA}

Jalur pedestrian adalah salah satu jalur sirkulasi yang banyak ditemui di kota-kota besar. Dharmawan (2004) mengatakan bahwa pedestrian berasal dari bahasa Latin yaitu pedestres, yang berarti orang yang berjalan kaki. Pedestrian pertama kali dikenal pada tahun 6000 SM di Khirokitia, Cyprus, untuk menyebut jalan yang terbuat dari batu gamping yang permukannya ditinggikan terhadap tanah dan dibuat ramp untuk menuju ke kelompok hunian pada kedua sisi-sisinya (Kostof, 1992). Selain itu pedestrian dapat diartikan pula pergerakan orang atau manusia melalui media jalan menuju ke tempat tujuan dengan menggunakan moda jalan kaki.

Pada era kini jalur pedestrian menjadi salah satu elemen penting perancangan kota (H. Shirvani, 1985). Jalur pedestrian merupakan sarana infrastruktur fisik berupa jalan/jalur yang diperuntukan bagi aktifitas para pengguna jalan. Hadirnya pedestrian ini harus mendukung interaksi antar elemen perancangan kota yang lain, berhubungan erat dengan lingkungan terbangun yang telah ada dan pola aktivitas dan harus sesuai dengan perubahan fisik kota.

Kebutuhan akan pedestrian sendiri dibuat jika suatu lahan berpotensi menimbulkan jalur pejalan kaki (Iswanto, 2006). Kategori lahan yang berpotensi ini dimaksudkan dengan pembangunan fasilitas publik maupun gedung-gedung komersial.

\section{Dimensi Pedestrian}

Dimensi ruang pedestrian harus memenuhi kebutuhan pergerakan penggunanya, karena faktor dimensi pedestrian akan berpengaruh terhadap aspek visual, yang sudah barang tentu akan membawa pengaruh pula pada kenyamanan dan privasi pengguna. Adapun dimensi pedestrian sebagai berikut (Wibawa, 1998):

1. Jarak antara $0-1.83$ meter merupakan jarak untuk pedestrian melakukan aktivitas umum.

2. Jarak antara $2.74-3.44$ meter merupakan jarak yang nyaman untuk melakukan belanja.

3. Jarak antara $3.00-5.00$ meter merupakan area pedestrian yang cukup untuk menampung PKL.

4. Jarak antara 4.57 - 5.49 meter merupakan jarak yang nyaman untuk jalan biasa.

5. Jarak > 10.67 meter merupakan jarak yang bebas untuk berjalan.

\section{Jenis Kegiatan di Pedestrian}

Rapoport (1977) mengklasifikasikan kegiatan yang terjadi di jalan dan jalur pejalan kaki sebagai berikut:

1. Pergerakan non-pedestrian, yaitu segala bentuk kendaraan beroda dan alat angkut lainnya.

2. Aktivitas pedestrian, meliputi aktivitas pedestrian yang dinamis atau bergerak sebagai manifestasi fungsi transportasi dan aktivitas pedestrian yang statis seperti duduk dan sebagainnya.

Menurut Mouden (dalam Sanjaya, 2017) bahwa semua aktivitas termasuk aktivitas pedestrian mengandung empat hal yaitu :

1. Aktivitas yang sebenarnya: berjalan, makan, dan lain-lain.

2. Cara melakukan: berjalan di jalur pedestrian, makan di rumah, dan lain-lain.

3. Aktivitas tambahan terkait dalam satu kesatuan sistem aktivitas seperti: berjalan sambil melihat etalase toko (window shopping).

4. Makna dari aktivitas: menghayati lingkungan dan lain sebagainya.

\section{Sarana dan Prasarana Pedestrian}

Permen PU No. 03/PRT/M/2014 menjelaskan bahwa Prasarana pedestrian terbagi atas:

1. Jalur pedestrian (trotoar)

2. Penyeberangan:

a. Sebidang: zebra cross dan pelican cross.

b. Tidak sebidang: jembatan penyeberangan dan terowongan.

Sementara sarana pendukung tersebut antara lain:

1. Jalur hijau

2. Lampu penerangan

3. Tempat duduk

4. Pagar pengaman 

5. Tempat sampah
6. Perambuan dan signage (papan informasi)
7. Halte/shelter bus dan lapak tunggu
8. Telepon umum
9. Rak sepeda
10. Leretan

\section{METODE PENELITIAN}

\section{Metode Penelitian}

Jenis metoda penelitian yang digunakan adalah deskriptif kualitatif. Penelitian deskriptif kualitatif adalah penelitian yang menggambarkan atau melukiskan objek penelitian berdasarkan fakta-fakta yang tampak atau sebagaimana adanya (Nawawi dan Martini, 1996, p.73). Penelitian deskriptif kualitatif berusaha mendeskripsikan seluruh gejala atau keadaan yang ada, yaitu keadaan gejala menurut apa adanya pada saat penelitian dilakukan (Mukhtar (2013, p.28).

\section{Objek Penelitian}

Penelitian ini bertujuan untuk mengidentifikasi pola pengguna jalan pada pemanfaatan jalur pedestrian sepanjang koridor Jalan Embong Malang Surabaya. Metode ini mendeskripsikan kondisi existing yang ada dan menganalisa secara kualitatif. Objek penelitian adalah jalur pedestrian sepanjang koridor Jalan Embong Malang Surabaya.

\section{Pengambilan Data}

1. Data Primer, melalui observasi

Observasi menggunakan teknik pengamatan Place Centered Maps dengan menitikberatkan kondisi existing pedestrian Embong Malang Surabaya, dan Person Centered Maps dengan mengamati pola perilaku penggunanya.

Place Centered Maps yaitu teknik pengamatan yang digunakan untuk mengetahui bagaimana manusia atau sekelompok manusia memanfaatkan, menggunakan dan mengakomodasikan perilakunya dalam suatu waktu pada tempat tertentu.

Person Centered Maps yaitu pengamatan yang menekankan pada pergerakan manusia pada periode waktu tertentu, dimana teknik ini berkaitan dengan tidak hanya satu tempat atau lokasi, akan tetapi beberapa tempat / lokasi.

Untuk mempermudah proses pengamatan digunakan ketegorisasi yaitu:

a. Hari pengamatan:

1) Senin-Jumat (hari kerja)

2) Sabtu-Minggu (hari libur)

b. Waktu pengamatan

1) Pukul $11.00-13.00$ (siang hari)

2) Pukul 15.00-17.00 (sore hari)

2. Data Sekunder, berupa pustaka.

\section{HASIL PEMBAHASAN}

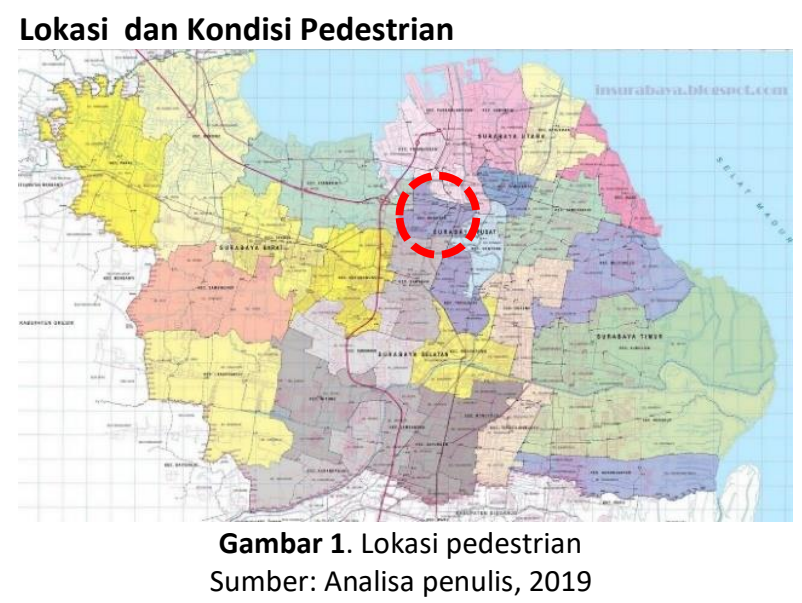

Penelitian ini mengambil lokasi di pedestrian Jalan Embong Malang Surabaya, dimana termasuk salah satu Jalan Arteri di Surabaya. Terletak di kawasan Central Business District (CBD). Pedestrian ini dikelilingi bangunan dengan kegiatan perdagangan dan jasa besar pada area selatan, dan kegiatan ekonomi kecil beserta hunian warga pada bagian utara.

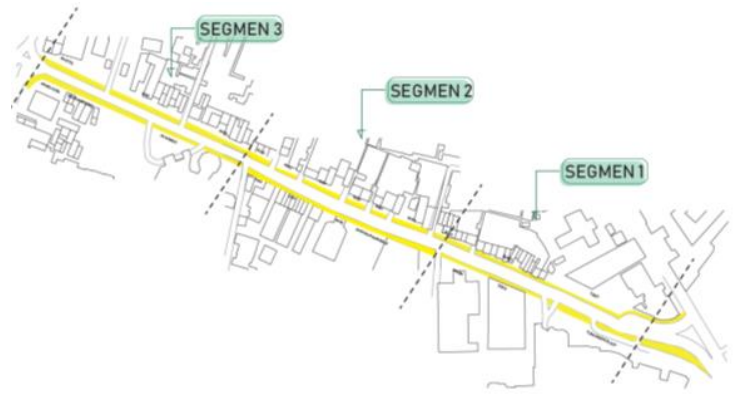

Gambar 2. Pedestrian Embong Malang Sumber: Analisa penulis, 2019

Terdapat dua jalur pedestrian berdasarkan posisinya yaitu pedestrian utara dan pedestrian selatan. Masing-masing pedestrian memiliki lebar rata-rata antara $3 \mathrm{~m}$ dan $7 \mathrm{~m}$. Panjang total dari Jl. Embong Malang sendiri adalah \pm 824 meter dengan kondisi pedestrian berkeramik dan terawat.

Hasil observasi kedua ruas pedestrian memiliki fasilitas dan tingkat penggunaan koridor pedestrian yang berbeda. Analisis dibagi tiga segmen pedestrian Jalan Embong Malang, dimana penanda segmen berupa gang warga pada area pedestrian selatan yaitu:

1. Pedestrian Segmen 1 meliputi Tunjungan Plaza di Pedestrian Selatan dan sejajarnya hingga Jl. Plemahan Besar.

2. Pedestrian Segmen 2 meliputi JI. Plemahan Besar di Pedestrian Selatan dan sejajarnya hingga Jl. Kedungturi Besar.

3. Pedestrian Segmen 3 meliputi Jl. Kedungturi Besar di Pedestrian Selatan dan sejajarnya hingga Jl. Kedungdoro. 


\section{Analisis setting fasilitas pedestrian}

Analisis setting pedestrian ini menggunakan teknik pengamatan place centered maps dengan menekankan kondisi fisik (fasilitas) yang ada pada pedestrian. Berdasarkan hasil observasi terdapat perbedaan fasilitas dan dimensi pada kedua pedestrian. Gambar 3-5 merupakan pemetaan fasilitas pedestrian berdasarkan segmen:

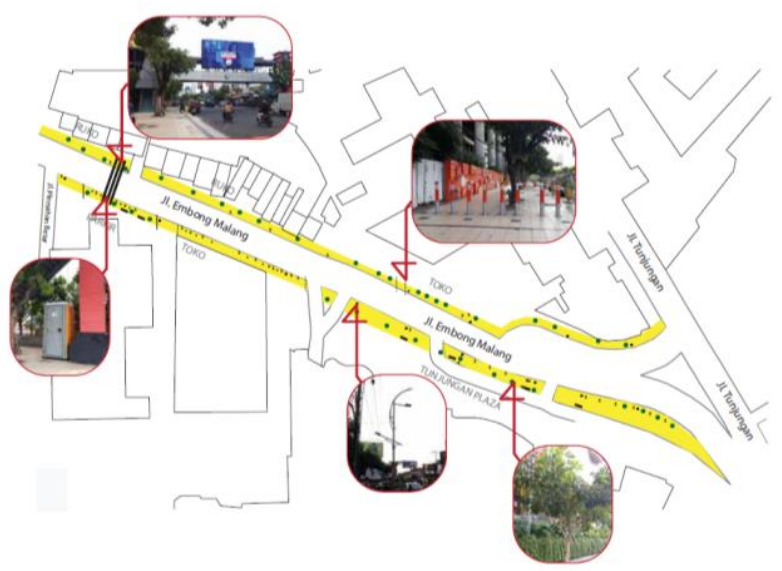

Gambar 3. Peta Fasilitas Pedestrian Segmen 1 Sumber: Analisa penulis, 2019

Pada segmen 1 terdapat fasilitas Jembatan Penyebrangan Orang (JPO) yang menghubungkan pedestrian utara dengan selatan. Pada JPO ini juga terfasilitasi toilet umum portable pada area pedestrian selatan sedangkan tidak disediakan pada area pedestrian utara.

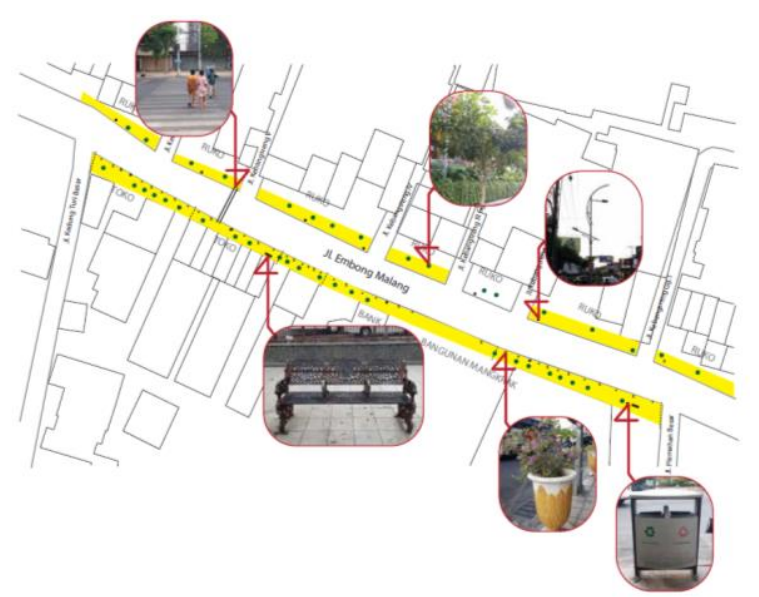

Gambar 4. Peta Fasilitas Pedestrian Segmen 2 Sumber: Analisa penulis, 2019

Pada segmen 2 terdapat fasilitas zebracross dan dilengkapi lampu lalu lintas yang menghubungkan pedestrian utara dengan selatan. Fasilitas zebracross ini sendiri merupakan salah satu akses penghubung pedestrian utara dan selatan selain menggunakan JPO.

Untuk memudahkan pengelompokan kualitas fasilitas pedestrian, analisis menggunakan parameter sederhana berdasarkan data hasil observasi:

1. Bisa difungsikan, yaitu fasilitas yang disediakan dapat difungsikan sebagaimana fungisnya.
2. Terawat, yaitu fasilitas terjaga dari segi kebersihan.

3. Bisa difungsikan dan terawat, yaitu fasilitas memenuhi kedua perameter penulis.

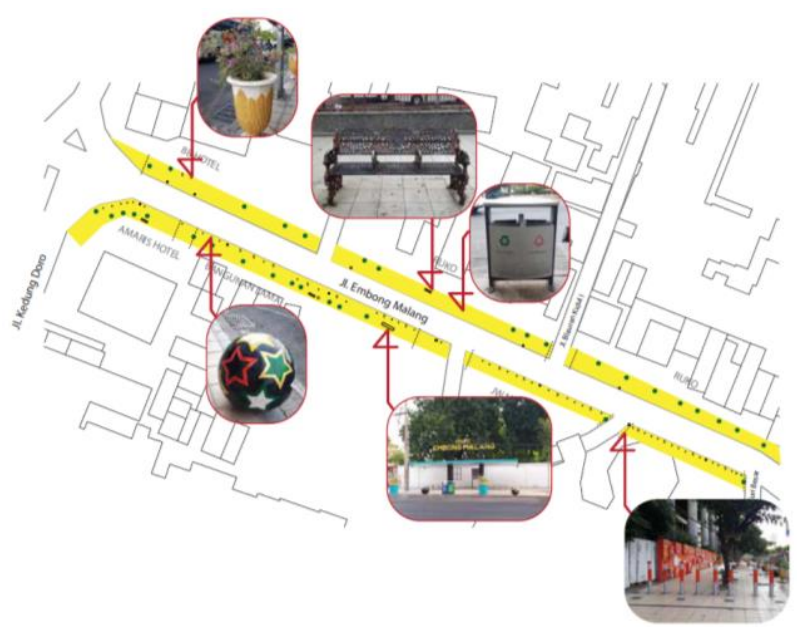

Gambar 5. Peta Fasilitas Pedestrian Segmen 3 Sumber: Analisa penulis, 2019

\section{Pedestrian Utara}

Pedestrian utara memiliki dimensi lebar 3 meter dengan berkeramik berwarna krem dan coklat muda dan kondisi cukup baik.

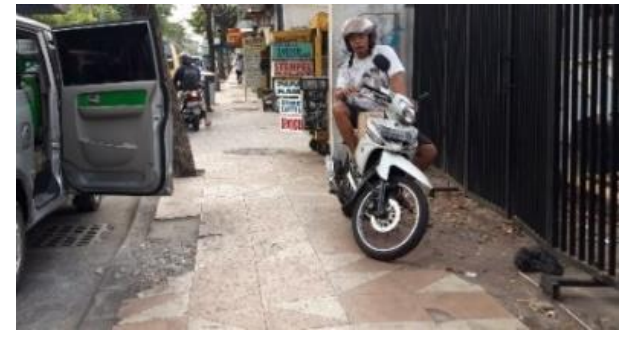

Gambar 6. Lebar jalan pedestrian utara Sumber: Analisa penulis 2019

Tabel 1 menunjukkan fasilitas yang disediakan pedestrian utara yaitu:

Tabel 1. Fasilitas Pedestrian Utara

\begin{tabular}{|c|c|c|c|}
\hline No. & Fasilitas & Jumlah & Kualitas \\
\hline 1 & Vegetasi & 66 & $\begin{array}{l}\text { Bisa difungsikan dan } \\
\text { terawat }\end{array}$ \\
\hline 2 & Lampu Taman & 22 & $\begin{array}{l}\text { Bisa difungsikan dan } \\
\text { terawat }\end{array}$ \\
\hline 3 & $\begin{array}{l}\text { Tempat } \\
\text { Sampah }\end{array}$ & 6 & $\begin{array}{l}\text { Bisa difungsikan dan } \\
\text { terawat }\end{array}$ \\
\hline 4 & $\begin{array}{l}\text { Tempat } \\
\text { duduk }\end{array}$ & 2 & $\begin{array}{l}\text { Bisa difungsikan dan } \\
\text { terawat }\end{array}$ \\
\hline 5 & $\begin{array}{l}\text { Portal } \\
\text { Pedestrian }\end{array}$ & 7 & $\begin{array}{l}\text { Bisa difungsikan dan } \\
\text { terawat }\end{array}$ \\
\hline 6 & Zebra Cross & 1 & $\begin{array}{l}\text { Bisa difungsikan dan } \\
\text { terawat }\end{array}$ \\
\hline 7 & $\begin{array}{l}\text { Jembatan } \\
\text { Penyebrangan } \\
\text { Orang }\end{array}$ & 1 & Bisa difungsikan \\
\hline 8 & Guiding block & $\begin{array}{c}20 \\
\text { meter }\end{array}$ & Bisa difungsikan \\
\hline
\end{tabular}


Pada pedestrian utara banyak didominasi rukoruko dan hunian warga sehingga terjadi beberapa kali perbedaan leveling pedestrian pada area gang-gang warga, serta kurang meratanya fasilitas seperti tempat duduk dan tempat sampah pada pedestrian utara segmen 1 dan 2 .

\section{Pedestrian Selatan}

Pedestrian selatan memiliki dimensi lebar 7 meter dengan material penutup keramik abu-abu dan kondisi baik.

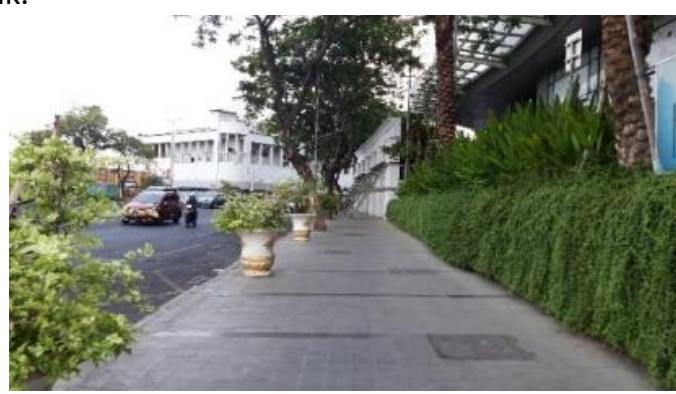

Gambar 7. Lebar jalan pedestrian selatan Sumber: Analisa penulis 2019

Tabel 2 menunjukkan fasilitas yang disediakan pada pedestrian selatan yaitu:

Tabel 2. Fasilitas Pedestrian Selatan

\begin{tabular}{clcl}
\hline No. & \multicolumn{1}{c}{ Fasilitas } & Jumlah & \multicolumn{1}{c}{ Kualitas } \\
\hline 1 & Vegetasi & 127 & $\begin{array}{l}\text { Bisa difungsikan } \\
\text { dan terawat }\end{array}$ \\
\hline 2 & Lampu Taman & 21 & $\begin{array}{l}\text { Bisa difungsikan } \\
\text { dan terawat }\end{array}$ \\
\hline 3 & $\begin{array}{l}\text { Tempat } \\
\text { Sampah }\end{array}$ & 16 & $\begin{array}{l}\text { Bisa difungsikan } \\
\text { dan terawat }\end{array}$ \\
\hline 4 & $\begin{array}{l}\text { Tempat } \\
\text { duduk }\end{array}$ & 13 & $\begin{array}{l}\text { Bisa difungsikan } \\
\text { dan terawat }\end{array}$ \\
\hline 5 & $\begin{array}{l}\text { Portal } \\
\text { Pedestrian }\end{array}$ & 20 & $\begin{array}{l}\text { Bisa difungsikan } \\
\text { dan terawat }\end{array}$ \\
\hline 6 & $\begin{array}{l}\text { Zebra Cross } \\
\text { Bebran difungsikan }\end{array}$ \\
\hline 7 & $\begin{array}{l}\text { Jembatan } \\
\text { Penyebrangan } \\
\text { Orang }\end{array}$ & 1 & $\begin{array}{l}\text { Bisa difungsikan } \\
\text { dan terawat }\end{array}$ \\
\hline 8 & $\begin{array}{l}\text { Pembatas } \\
\text { pedestrian }\end{array}$ & 81 & $\begin{array}{l}\text { Bisa difungsikan } \\
\text { dan terawat }\end{array}$ \\
\hline 9 & Halte & 1 & $\begin{array}{l}\text { Bisa difungsikan } \\
\text { dan terawat }\end{array}$ \\
\hline 10 & Toilet Portable & 1 & Bisa difungsikan \\
\hline Adanya fasilitas pembatas & pedestrian berupa
\end{tabular}

bola-bola dan vegetasi berupa pohon dan pot bunga.

Serta persebaran fasilitas cenderung runtut dan merata dibanding pedestrian bagian utara.

\section{Analisis setting perilaku pengguna pedestrian}

Analisis setting perilaku pengguna pedestrian ini mengunakan teknik pengamatan person centered maps dengan mengamati perilaku pengguna pedestrian berdasakan periodesasi waktu pengamatan siang dan sore.
Analisis dilakukan dengan membuat pengelompokan tingkat pengguna pedestrian dengan parameter sederhana berdasarkan data hasil observasi:

1. Ramai, yaitu pengguna pedestrian lebih dari 15 orang

2. Sedang, yaitu pengguna pedestrian 5-15 orang

3. Sepi, yaitu pengguna pedestrian 0-5 orang.

Berikut pemetaan tingkat pengguna pedestrian berdasarkan segmen:

Segmen 1, Hari kerja (Siang Pukul 11.00-13.00)

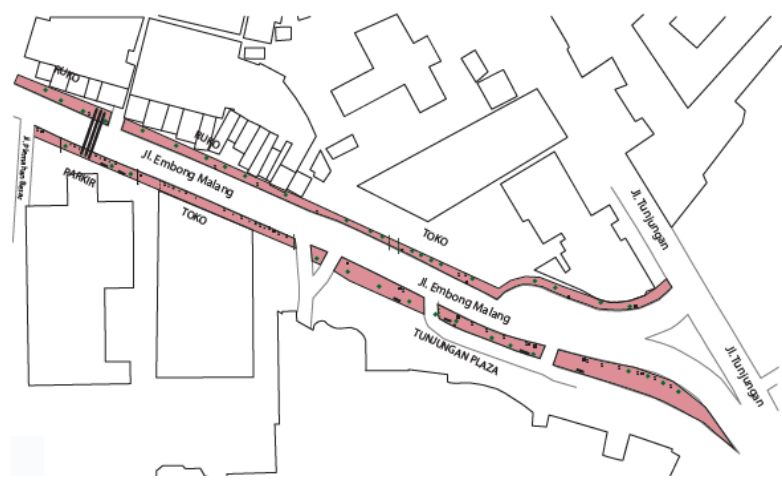

Gambar 8. Peta tingkat pengguna pedestrian hari kerja siang segmen 1 Sumber: Analisa penulis, 2019

Tingkat pengguna pedestrian hari kerja siang hari pada segmen 1 masuk kategori sedang. Pada pedestrian utara didominasi kegiatan ekonomi dan pedestrian selatan didominasi pejalan kaki dari Tunjungan Plaza.

1. Pedestrian Utara

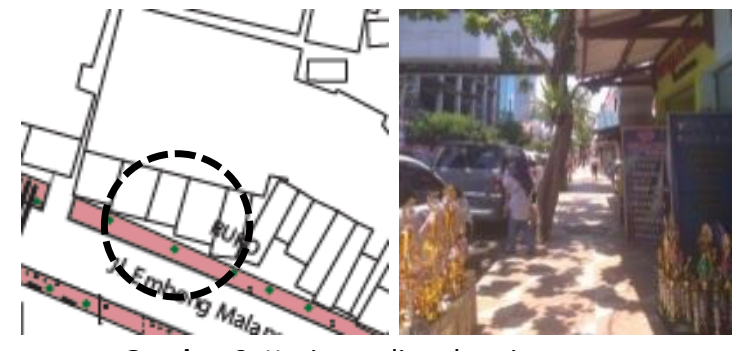

Gambar 9. Kegiatan di pedestrian utara Sumber: Analisa penulis, 2019

Pedestrian utara di segmen 1 terdiri dari deretan pertokoan dan di belakangnya merupakan kawasan hunian warga. Tabel 3 menunjukkan tingkat pengguna pedestrian utara yaitu:

Tabel 3. Tingkat Pengguna Pedestrian Utara

\begin{tabular}{lll}
\hline Kawasan & $\begin{array}{l}\text { Tingkat } \\
\text { Penguna }\end{array}$ & Jenis Aktivitas \\
\hline Pertokoan & Sedang & $\begin{array}{l}\text { Kegiatan dan proses jual } \\
\text { beli }\end{array}$ \\
\hline Parkiran & Sedang & $\begin{array}{l}\text { Akses keluar masuk } \\
\text { parkiran }\end{array}$ \\
\hline
\end{tabular}




\section{Pedestrian Selatan}

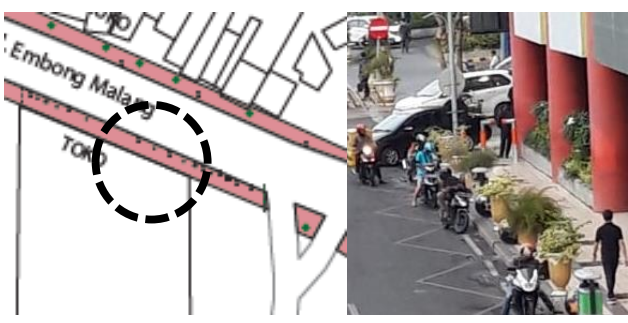

Gambar 10. Kegiatan di pedestrian selatan Sumber: Analisa penulis, 2019

Pedestrian selatan di segmen 1 terdiri dari area Tunjungan Plaza dan Pertokoan. Tabel 4 menunjukkan tingkat pengguna pedestrian selatan yaitu:

Tabel 4. Tingkat Pengguna Pedestrian Selatan

\begin{tabular}{lll}
\hline Kawasan & $\begin{array}{l}\text { Tingkat } \\
\text { Penguna }\end{array}$ & Jenis Aktivitas \\
\hline $\begin{array}{l}\text { Tunjungan } \\
\text { Plaza }\end{array}$ & Sedang & $\begin{array}{l}\text { Akses keluar masuk menuju } \\
\text { Tunjungan Plaza }\end{array}$ \\
\hline Pertokoan & Sedang & $\begin{array}{l}\text { Kegiatan dan proses jual beli } \\
\text { Tempat ojek online } \\
\end{array}$ \\
& & menunggu penumpang \\
\hline
\end{tabular}

Segmen 2, Hari kerja (Siang Pukul 11.00-13.00)

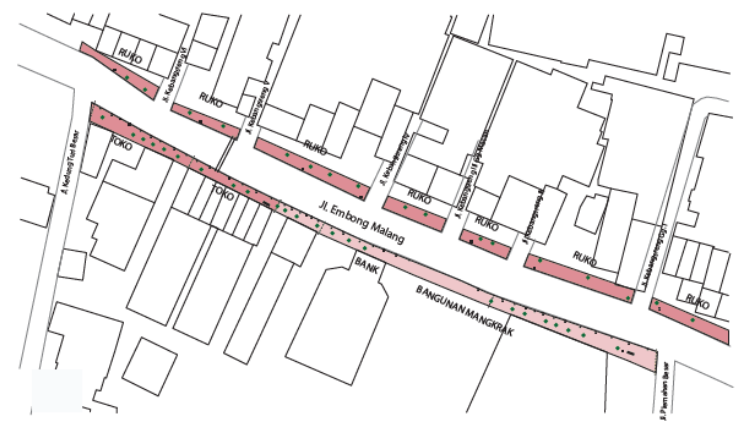

Gambar 11. Peta tingkat pengguna pedestrian hari kerja siang segmen 2 (Sumber: Analisa penulis, 2019)

Tingkat pengguna pedestrian segmen 2 berbeda antara kedua pedestrian. Pada pedestrian utara tingkat kegiatan masih kategori sedang sedangkan pada pedestrian selatan menurun pada area konstruksi bangunan dan bank dan kembali naik (kategori sedang) pada area pertokoan.

\section{Pedestrian Utara}

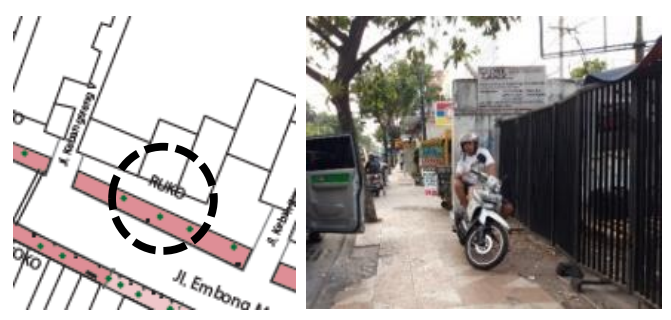

Gambar 12. Kegiatan di pedestrian utara (Sumber: Analisa penulis, 2019)
Pedestrian utara di segmen 2 terdiri dari deretan pertokoan dan gang-gang menuju kawasan hunian warga. Tabel 5 menunjukkan tingkat pengguna pedestrian utara yaitu:

Tabel 5. Tingkat Pengguna Pedestrian Utara

\begin{tabular}{lll}
\hline Kawasan & $\begin{array}{l}\text { Tingkat } \\
\text { Penguna }\end{array}$ & Jenis Aktivitas \\
\hline Pertokoan & Sedang & Kegiatan dan proses jual beli \\
\hline $\begin{array}{l}\text { Gang hunian } \\
\text { warga }\end{array}$ & Sedang & $\begin{array}{l}\text { Akses keluar masuk menuju } \\
\text { hunian warga }\end{array}$ \\
\hline
\end{tabular}

\section{Pedestrian Selatan}

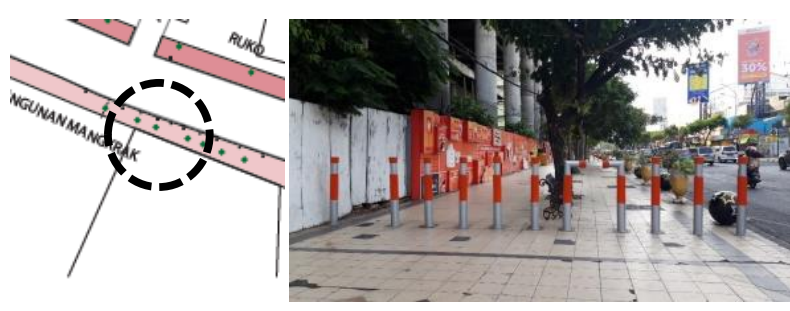

Gambar 13. Kegiatan di pedestrian selatan Sumber: Analisa penulis 2019

Pedestrian selatan di segmen 2 terdiri dari konstruksi bangunan setengah jadi, bank, dan area pertokoan. Tabel 6 menunjukkan tingkat pengguna pedestrian utara yaitu:

Tabel 6. Tingkat Pengguna Pedestrian Selatan

\begin{tabular}{lll}
\hline Kawasan & $\begin{array}{l}\text { Tingkat } \\
\text { Penguna }\end{array}$ & Jenis Aktivitas \\
\hline $\begin{array}{l}\text { Bangunan } \\
\text { Konstruksi }\end{array}$ & Sepi & $\begin{array}{l}\text { Kegiatan cenderung tidak } \\
\text { ada }\end{array}$ \\
\hline Bank & Sepi & $\begin{array}{l}\text { Kegiatan cenderung tidak } \\
\text { ada }\end{array}$ \\
\hline Pertokoan & Sedang & $\begin{array}{l}\text { Kegiatan dan proses jual } \\
\text { beli }\end{array}$ \\
\hline
\end{tabular}

Segmen 3, Hari kerja (Siang Pukul 11.00-13.00)

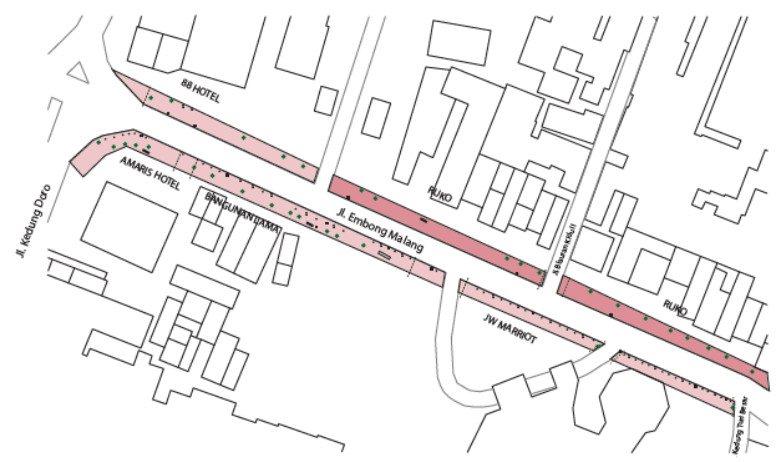

Gambar 14. Peta tingkat pengguna pedestrian hari kerja siang segmen 3 (Sumber: Analisa penulis 2019)

Tingkat pengguna pedestrian utara kategori sedang pada area pertokoan dan kategori rendah pada area hotel sedangkan pedestrian selatan cenderung rendah. 


\section{Pedestrian Utara}

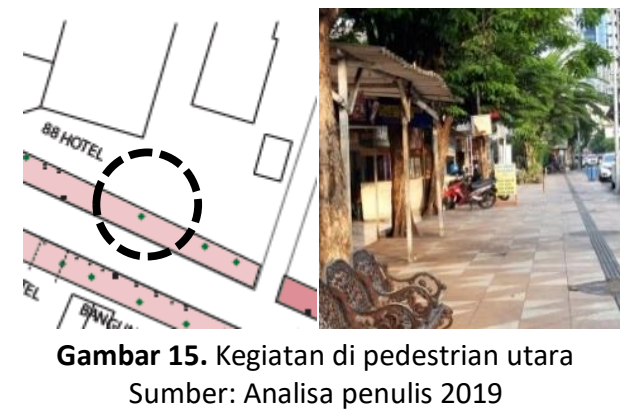

Pedestrian utara segmen 3 terdiri dari area pertokoan dan hotel. Tabel 7 menunjukkan tingkat pengguna pedestrian utara yaitu:

Tabel 7. Tingkat Pengguna Pedestrian Utara

\begin{tabular}{lll}
\hline Kawasan & $\begin{array}{l}\text { Tingkat } \\
\text { Penguna }\end{array}$ & Jenis Aktivitas \\
\hline Pertokoan & Sedang & $\begin{array}{l}\text { Kegiatan dan proses jual } \\
\text { beli }\end{array}$ \\
\hline Hotel & Sepi & $\begin{array}{l}\text { Kegiatan cenderung } \\
\text { tidak ada }\end{array}$ \\
\hline
\end{tabular}

\section{Pedestrian Selatan}

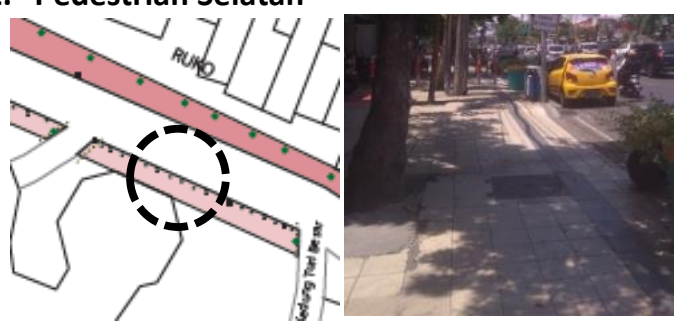

Gambar 16. Kegiatan di pedestrian selatan (Sumber: Analisa penulis, 2019)

Pedestrian utara segmen 3 terdiri dari area pertokoan dan hotel. Tabel 8 menunjukkan tingkat pengguna pedestrian utara yaitu:

Tabel 8. Tingkat Pengguna Pedestrian Selatan

\begin{tabular}{lll}
\hline Kawasan & $\begin{array}{l}\text { Tingkat } \\
\text { Penguna }\end{array}$ & Jenis Aktivitas \\
\hline Hotel & Sepi & $\begin{array}{l}\text { Kegiatan cenderung tidak } \\
\text { ada }\end{array}$ \\
\hline Halte & Sepi & Menunggu bis \\
\hline
\end{tabular}

Segmen 1, Hari kerja (Sore Pukul 15.00-17.00)

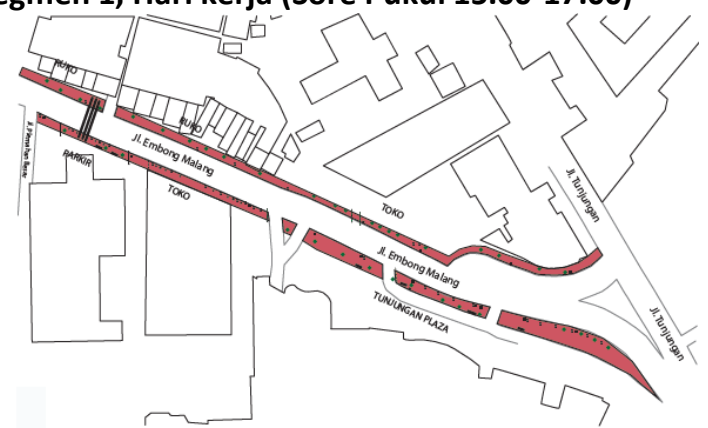

Gambar 17. Peta tingkat pengguna pedestrian hari kerja sore segmen 1 (Sumber: Analisa penulis 2019)
Pada segmen 1 tingkat pengguna pedestrian sore hari tinggi dan ramai. Kegiatan pedestrian sore hari didominasi kegiatan akses keluar masuk di parkiran dan pejalan kaki sedangkan pada pedestrian selatan didominasi area Tunjungan Plaza.

\section{Pedestrian Utara}

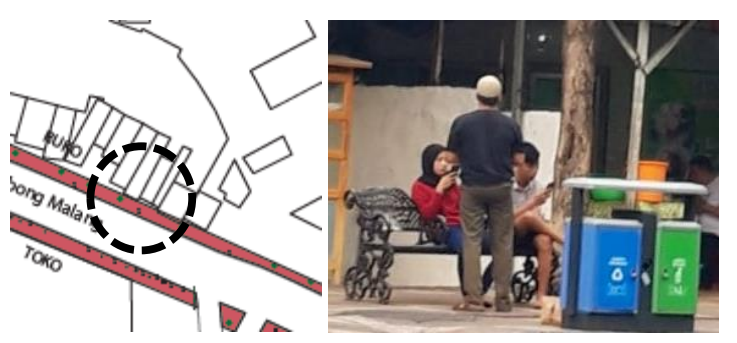

Gambar 18. Kegiatan di pedestrian utara Sumber: Analisa penulis 2019

Tabel 9 menunjukkan tingkat pengguna pedestrian utara yaitu:

Tabel 9. Tingkat Pengguna Pedestrian Utara

\begin{tabular}{lll}
\hline Kawasan & $\begin{array}{l}\text { Tingkat } \\
\text { Penguna }\end{array}$ & Jenis Aktivitas \\
\hline Pertokoan & Ramai & Kegiatan dan proses jual beli \\
\hline Parkiran & Ramai & Akses keluar masuk parkiran \\
\hline
\end{tabular}

\section{Pedestrian Selatan}

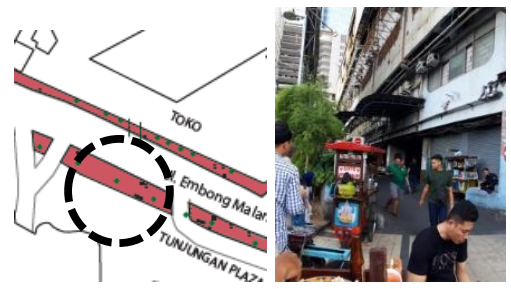

Gambar 19. Kegiatan di pedestrian selatan Sumber: Analisa penulis 2019

Tabel 10 menunjukkan tingkat pengguna pedestrian utara yaitu:

Tabel 10. Tingkat Pengguna Pedestrian Selatan

\begin{tabular}{lll}
\hline Kawasan & $\begin{array}{l}\text { Tingkat } \\
\text { Penguna }\end{array}$ & Jenis Aktivitas \\
\hline $\begin{array}{l}\text { Tunjungan } \\
\text { Plaza }\end{array}$ & Ramai & Jual beli pedagang kaki lima \\
\hline Pertokoan & Ramai & $\begin{array}{l}\text { Tempat ojek online } \\
\text { menunggu penumpang }\end{array}$ \\
\hline
\end{tabular}

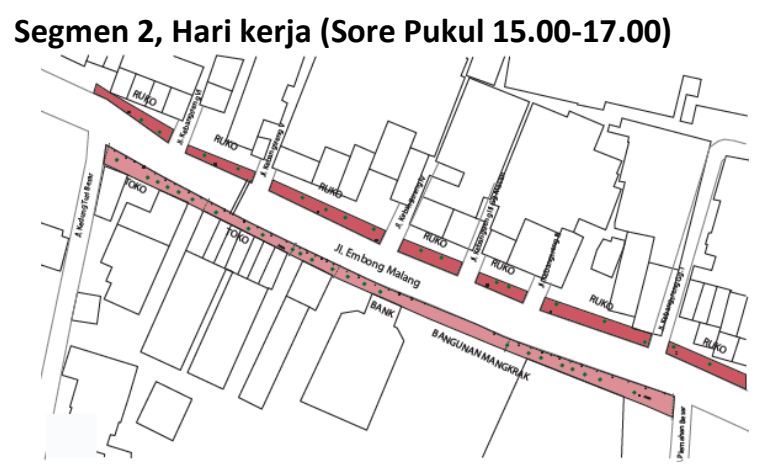

Gambar 20. Peta tingkat pengguna pedestrian hari kerja sore segmen 2 Sumber: Analisa penulis 2019 
Pada pedestrian segmen 2, kegiatan pedestrian utara ramai dengan didominasi kegiatan perdagangan dan jasa sedangkan pada pedestrian selatan kategori sedang dengan didominasi pejalan kaki.

1. Pedestrian Utara

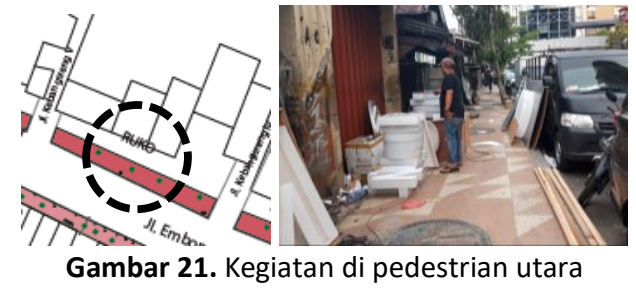

(Sumber: Analisa penulis, 2019)

Tabel 11 menunjukkan tingkat pengguna pedestrian utara yaitu:

Tabel 11. Tingkat Pengguna Pedestrian Utara

\begin{tabular}{lll}
\hline Kawasan & $\begin{array}{l}\text { Tingkat } \\
\text { Penguna }\end{array}$ & Jenis Aktivitas \\
\hline Pertokoan & Ramai & $\begin{array}{l}\text { Kegiatan dan proses jual } \\
\text { beli }\end{array}$ \\
\hline $\begin{array}{l}\text { Gang hunian } \\
\text { warga }\end{array}$ & Ramai & $\begin{array}{l}\text { Akses keluar masuk menuju } \\
\text { hunian warga }\end{array}$ \\
\hline
\end{tabular}

\section{Pedestrian Selatan}

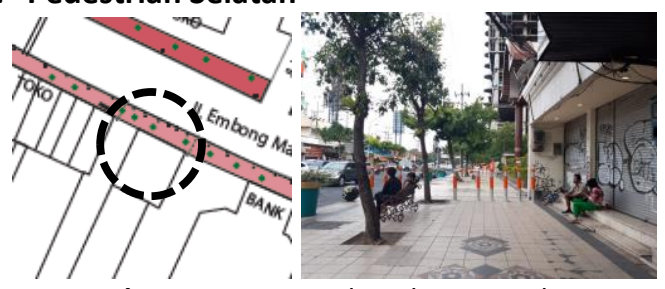

Gambar 22. Kegiatan di pedestrian selatan

(Sumber: Analisa penulis, 2019)

Tabel 12 menunjukkan tingkat pengguna pedestrian utara yaitu:

Tabel 12. Tingkat Pengguna Pedestrian Selatan

\begin{tabular}{lll}
\hline Kawasan & $\begin{array}{l}\text { Tingkat } \\
\text { Penguna }\end{array}$ & Jenis Aktivitas \\
\hline $\begin{array}{l}\text { Bangunan } \\
\text { Konstruksi }\end{array}$ & Sedang & Lalu lintas pejalan kaki \\
\hline Bank & Sedang & Lalu lintas pejalan kaki \\
\hline Pertokoan & Sedang & Kegiatan jual beli \\
\hline
\end{tabular}

\section{Segmen 3, Hari kerja (Sore Pukul 15.00-17.00)}

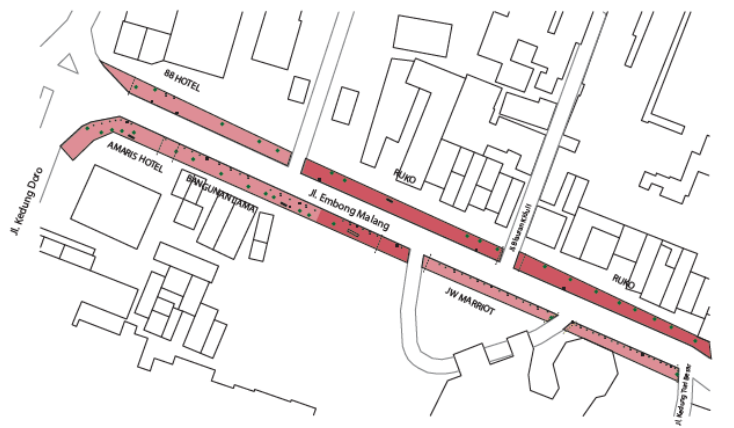

Gambar 23. Peta tingkat pengguna pedestrian hari kerja sore segmen 3 (Sumber: Analisa penulis 2019)

Pada segmen 3 tingkat pengguna pedestrian berfokus pada area tertentu yaitu ruko pada area utara dan halte pada area selatan dengan tingkat pengguna tinggi.

\section{Pedestrian Utara}

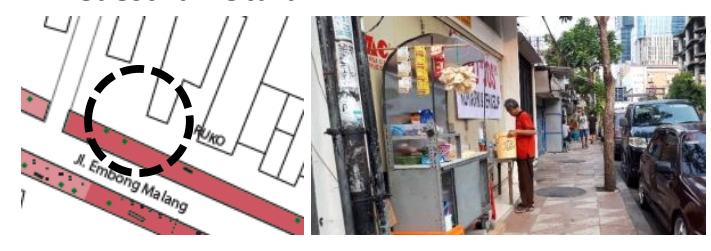

Gambar 24. Kegiatan di pedestrian utara

(Sumber: Analisa penulis, 2019)

Tabel 13 menunjukkan tingkat pengguna pedestrian utara yaitu:

Tabel 13. Tingkat Pengguna Pedestrian Utara

\begin{tabular}{lll}
\hline Kawasan & $\begin{array}{l}\text { Tingkat } \\
\text { Penguna }\end{array}$ & Jenis Aktivitas \\
\hline Pertokoan & Ramai & Kegiatan dan proses jual beli \\
\hline Hotel & Sedang & Lalu lintas pejalan kaki \\
\hline
\end{tabular}

\section{Pedestrian Selatan}

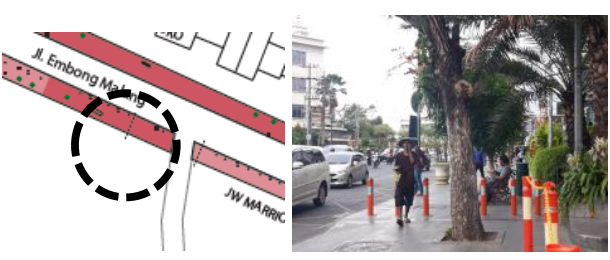

Gambar 25. Kegiatan di pedestrian selatan

(Sumber: Analisa penulis, 2019)

Tabel 14 menunjukkan tingkat pengguna pedestrian utara yaitu:

Tabel 14. Tingkat Pengguna Pedestrian Selatan

\begin{tabular}{lll}
\hline Kawasan & $\begin{array}{l}\text { Tingkat } \\
\text { Penguna }\end{array}$ & Jenis Aktivitas \\
\hline Hotel & Sedang & Lalu lintas pejalan kaki \\
\hline Halte & Ramai & Menunggu bis \\
\hline
\end{tabular}

\section{Segmen 1, Hari Libur (Siang Pukul 11.00-13.00)}

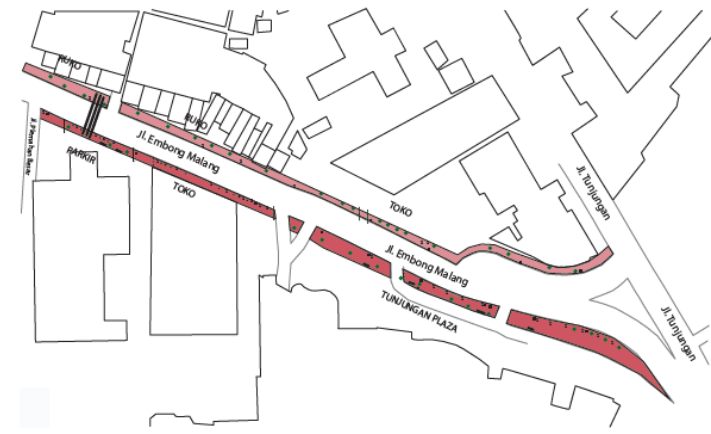

Gambar 26. Peta tingkat pengguna pedestrian hari libur siang segmen 1 (Sumber: Analisa penulis 2019)

Pada siang hari, terjadi perbedaan tingkat penguna. Pedestrian utara tingkat pengguna kategori sedang, didominasi pengguna yang menunggu di area parkiran sedangkan pada pedestrian selatan tingkat pengguna ramai dengan jenis kegiatan didominasi akses keluar masuk dari arah Tunjungan.

\section{Pedestrian Utara}




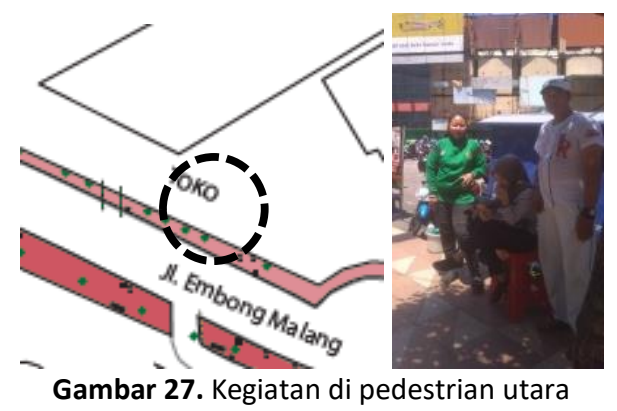

Sumber: Analisa penulis 2019

Tabel 15 menunjukkan tingkat pengguna pedestrian utara yaitu:

Tabel 15 . Tingkat Pengguna Pedestrian Utara

\begin{tabular}{lll}
\hline Kawasan & $\begin{array}{l}\text { Tingkat } \\
\text { Penguna }\end{array}$ & Jenis Aktivitas \\
\hline Pertokoan & Sedang & $\begin{array}{l}\text { Kegiatan dan proses jual } \\
\text { beli }\end{array}$ \\
\hline Parkiran & Sedang & Menunggu di area parkiran \\
\hline
\end{tabular}

\section{Pedestrian Selatan}

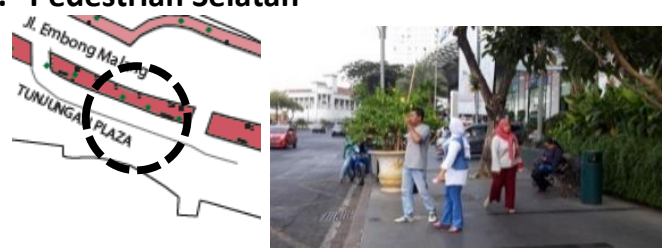

Gambar 28. Kegiatan di pedestrian selatan (Sumber: Analisa penulis, 2019)

Tabel 16 menunjukkan tingkat pengguna pedestrian selatan yaitu:

Tabel 16. Tingkat Pengguna Pedestrian Selatan

\begin{tabular}{lll}
\hline Kawasan & $\begin{array}{l}\text { Tingkat } \\
\text { Penguna }\end{array}$ & Jenis Aktivitas \\
\hline $\begin{array}{l}\text { Tunjungan } \\
\text { Plaza }\end{array}$ & Ramai & $\begin{array}{l}\text { Akses keluar masuk menuju } \\
\text { Tunjungan Plaza }\end{array}$ \\
\hline Pertokoan & Ramai & Kegiatan dan proses jual beli \\
\hline
\end{tabular}

\section{Segmen 2, Hari Libur (Siang Pukul 11.00-13.00)}

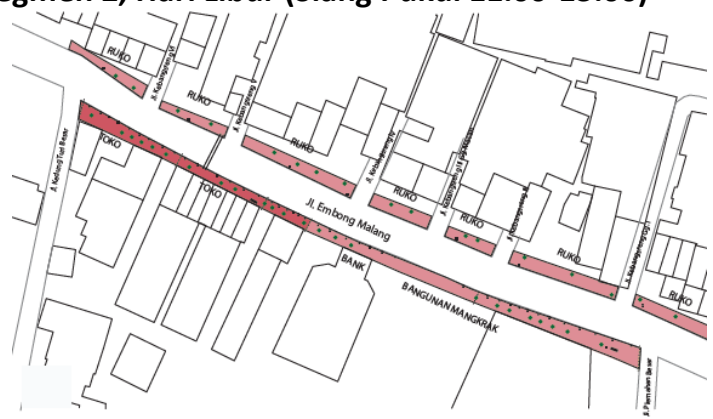

Gambar 29. Peta tingkat pengguna pedestrian hari libur siang segmen 2 (Sumber: Analisa penulis, 2019)

Tingkat pengguna pedestrian segmen 2 relatif sedang. Pada pedestrian utara didominasi kegiatan perdagangan dan jasa ruko sedangkan pada pedestrian selatan tingkat kegiatan pengguna berfokus di area toko-toko dibanding area bank.
1. Pedestrian Utara

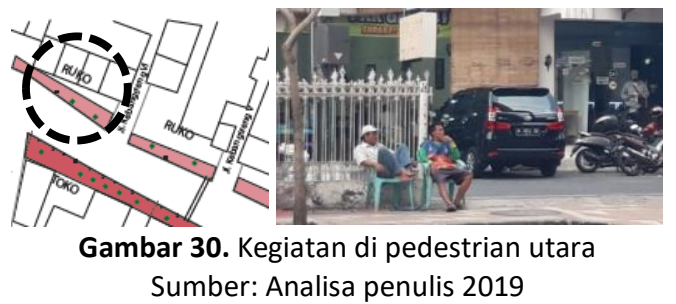

Tabel 17 menunjukkan tingkat pengguna pedestrian utara yaitu:

Tabel 17. Tingkat Pengguna Pedestrian Utara

\begin{tabular}{lll} 
Kawasan & $\begin{array}{l}\text { Tingkat } \\
\text { Penguna }\end{array}$ & Jenis Aktivitas \\
\hline Pertokoan & Sedang & $\begin{array}{l}\text { Kegiatan dan proses jual } \\
\text { beli }\end{array}$ \\
\hline $\begin{array}{l}\text { Gang hunian } \\
\text { warga }\end{array}$ & Sedang & $\begin{array}{l}\text { Akses keluar masuk } \\
\text { menuju hunian warga }\end{array}$ \\
\hline
\end{tabular}

\section{Pedestrian Selatan}

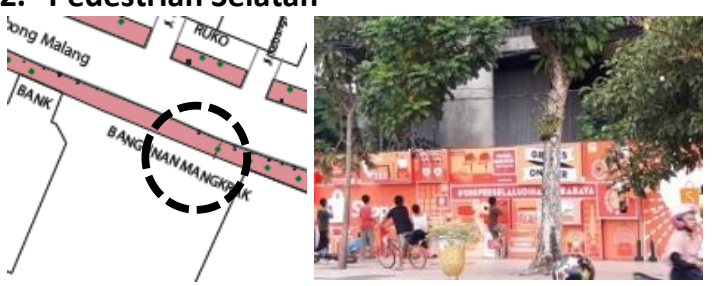

Gambar 31. Kegiatan di pedestrian selatan (Sumber: Analisa penulis, 2019)

Tabel 18 menunjukkan tingkat pengguna pedestrian selatan yaitu:

Tabel 18. Tingkat Pengguna Pedestrian Selatan

\begin{tabular}{lll} 
Kawasan & $\begin{array}{l}\text { Tingkat } \\
\text { Penguna }\end{array}$ & Jenis Aktivitas \\
\hline $\begin{array}{l}\text { Bangunan } \\
\text { Konstruksi }\end{array}$ & Sedang & Lalu lintas pejalan kaki \\
\hline Bank & Sedang & Lalu lintas pejalan kaki \\
\hline Pertokoan & Ramai & Kegiatan jual beli \\
\hline
\end{tabular}

\section{Segmen 3, Hari Libur (Siang Pukul 11.00-13.00)}

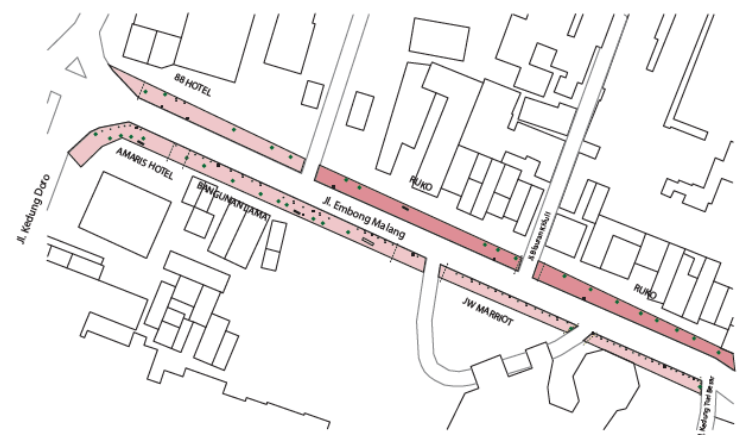

Gambar 32. Peta tingkat pengguna pedestrian hari libur siang segmen 3 (Sumber: Analisa penulis, 2019)

Pada pedestrian di segmen 3 tingkat pengguna pedestrian menurun. Pada pedestrian utara kegiatan sedang pada area ruko dan sepi pada area hotel sedangkan pada pedestrian selatan tingkat kegiatan rendah. 


\section{Pedestrian Utara}

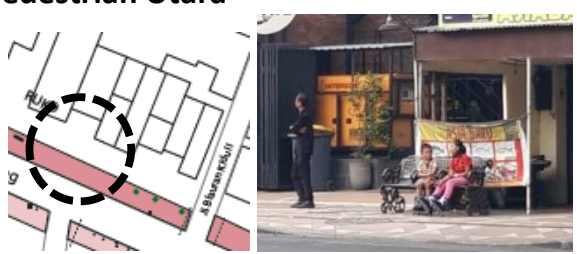

Gambar 33. Kegiatan di pedestrian utara

(Sumber: Analisa penulis, 2019)

Tabel 19 menunjukkan tingkat pengguna pedestrian utara yaitu:

Tabel 19. Tingkat Pengguna Pedestrian Utara

\begin{tabular}{lll}
\hline Kawasan & $\begin{array}{l}\text { Tingkat } \\
\text { Penguna }\end{array}$ & Jenis Aktivitas \\
\hline Pertokoan & Sedang & Kegiatan dan proses jual beli \\
\hline Hotel & Sepi & Lalu lintas pejalan kaki \\
\hline
\end{tabular}

\section{Pedestrian Selatan}

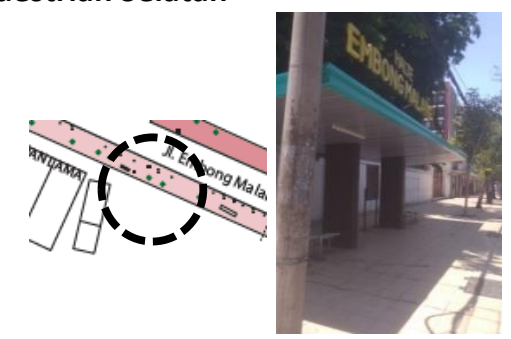

Gambar 34. Kegiatan di pedestrian selatan (Sumber: Analisa penulis, 2019)

Tabel 20 menunjukkan tingkat pengguna pedestrian utara yaitu:

Tabel 20. Tingkat Pengguna Pedestrian Selatan

\begin{tabular}{lll}
\hline Kawasan & $\begin{array}{l}\text { Tingkat } \\
\text { Penguna }\end{array}$ & Jenis Aktivitas \\
\hline Hotel & Sepi & Kegiatan cenderung tidak ada \\
\hline Halte & Sepi & Kegiatan cenderung tidak ada \\
\hline
\end{tabular}

Segmen 1, Hari Libur (Sore Pukul 15.00-17.00)

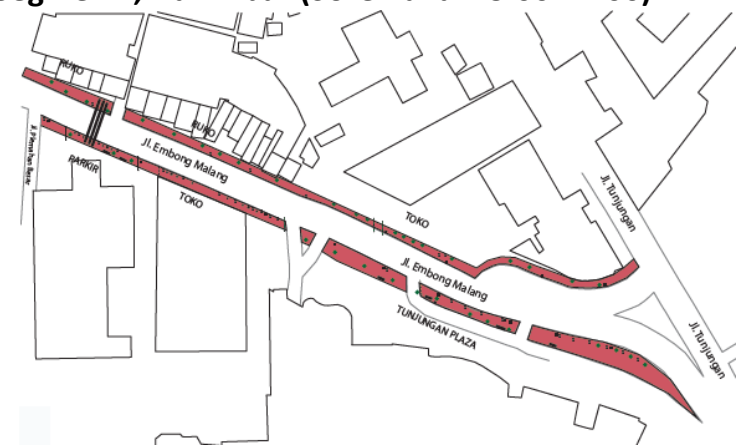

Gambar 35. Peta tingkat pengguna pedestrian hari libur sore segmen 1 (Sumber: Analisa penulis, 2019)

Pada hari libur sore hari, tingkat pengguna kedua pedestrian pada segmen 1 cenderung ramai. Jenis kegiatan pedestrian utara didominasi lalu lintas aktivitas perdagangan dan jasa dari ruko di sekitarnya.
Selain itu pengguna pedestrian terdiri dari para pekerja yang pulang dari bekerja.

1. Pedestrian Utara

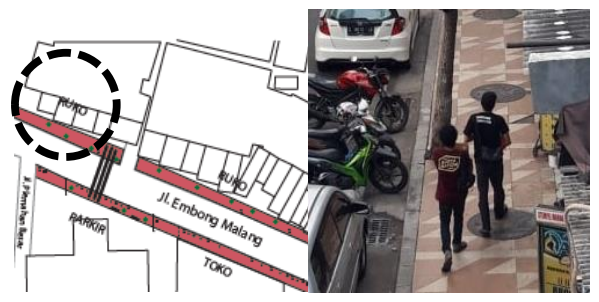

Gambar 36. Kegiatan di pedestrian utara

(Sumber: Analisa penulis, 2019)

Tabel 21 menunjukkan tingkat pengguna pedestrian utara yaitu:

Tabel 21 . Tingkat Pengguna Pedestrian Utara

\begin{tabular}{lll}
\hline Kawasan & $\begin{array}{l}\text { Tingkat } \\
\text { Penguna }\end{array}$ & Jenis Aktivitas \\
\hline Pertokoan & Ramai & $\begin{array}{l}\text { Kegiatan dan proses jual beli } \\
\text { Lalu lintas pejalan kaki }\end{array}$ \\
\hline Parkiran & Ramai & Menunggu di area parkiran \\
\hline
\end{tabular}

2. Pedestrian Selatan

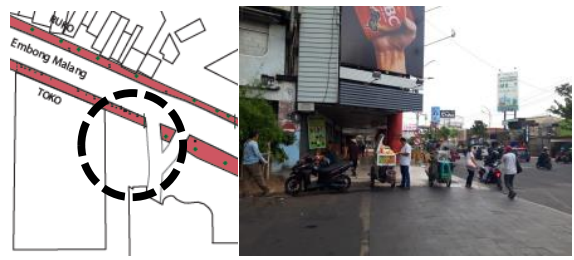

Gambar 37. Kegiatan di pedestrian selatan

(Sumber: Analisa penulis, 2019)

Tabel 22 menunjukkan tingkat pengguna pedestrian selatan yaitu:

Tabel 22. Tingkat Pengguna Pedestrian Selatan

\begin{tabular}{lll}
\hline Kawasan & $\begin{array}{l}\text { Tingkat } \\
\text { Penguna }\end{array}$ & Jenis Aktivitas \\
\hline Tunjungan & Ramai & $\begin{array}{l}\text { Akses keluar masuk menuju } \\
\text { Tunjungan Plaza }\end{array}$ \\
\hline Plaza & & Kegiatan dan proses jual beli \\
\hline
\end{tabular}

Segmen 2, Hari Libur (Sore Pukul 15.00-17.00)

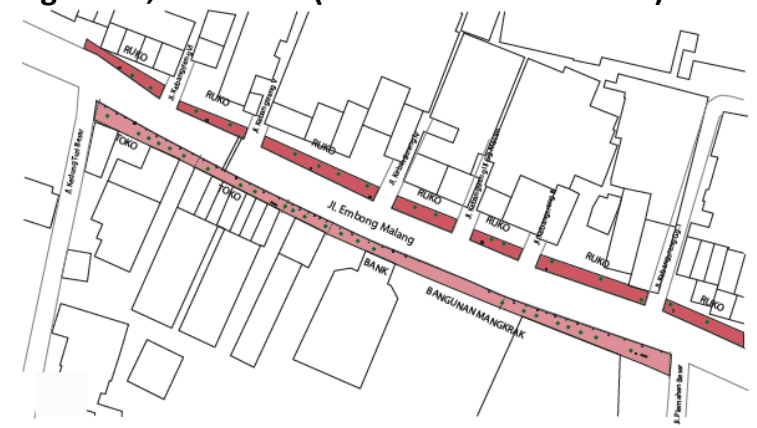

Gambar 38. Peta tingkat pengguna pedestrian hari libur sore segmen 2 (Sumber: Analisa penulis, 2019)

Sedangkan pada pedestrian segmen 2, tingkat pengguna pedestrian utara lebih tinggi dibanding pedestrian selatan. Jenis kegiatan pedestrian utara masih didominasi kegiatan perdagangan dan jasa 
dengan tingkat cenderung ramai. Dan kegiatan di pedestrian utara kategori sedang dengan didominasi oleh pejalan kaki.

\section{Pedestrian Utara}

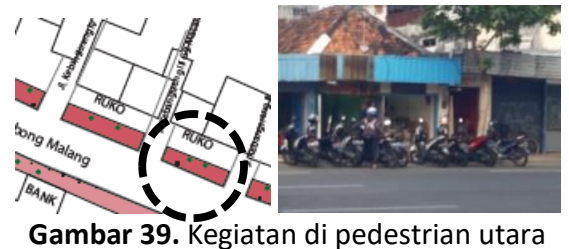

(Sumber: Analisa penulis, 2019)

Tabel 23 menunjukkan tingkat pengguna pedestrian utara yaitu:

Tabel 23. Tingkat Pengguna Pedestrian Utara

\begin{tabular}{lll}
\hline Kawasan & $\begin{array}{l}\text { Tingkat } \\
\text { Penguna }\end{array}$ & Jenis Aktivitas \\
\hline Pertokoan & Ramai & Kegiatan jual beli \\
\hline $\begin{array}{l}\text { Gang hunian } \\
\text { warga }\end{array}$ & Ramai & $\begin{array}{l}\text { Akses keluar masuk } \\
\text { menuju hunian warga }\end{array}$ \\
\hline
\end{tabular}

\section{Pedestrian Selatan}

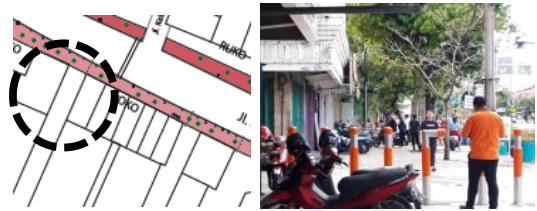

Gambar 40. Kegiatan di pedestrian selatan (Sumber: Analisa penulis, 2019)

Tabel 24 menunjukkan tingkat pengguna pedestrian selatan yaitu:

Tabel 24. Tingkat Pengguna Pedestrian Selatan

\begin{tabular}{lll}
\hline Kawasan & $\begin{array}{l}\text { Tingkat } \\
\text { Penguna }\end{array}$ & Jenis Aktivitas \\
\hline $\begin{array}{l}\text { Bangunan } \\
\text { Konstruksi }\end{array}$ & Sedang & Lalu lintas pejalan kaki \\
\hline Bank & Sedang & Lalu lintas pejalan kaki \\
\hline Pertokoan & Sedang & Kegiatan jual beli \\
\hline
\end{tabular}

\section{Segmen 3, Hari Libur (Sore Pukul 15.00-17.00)}

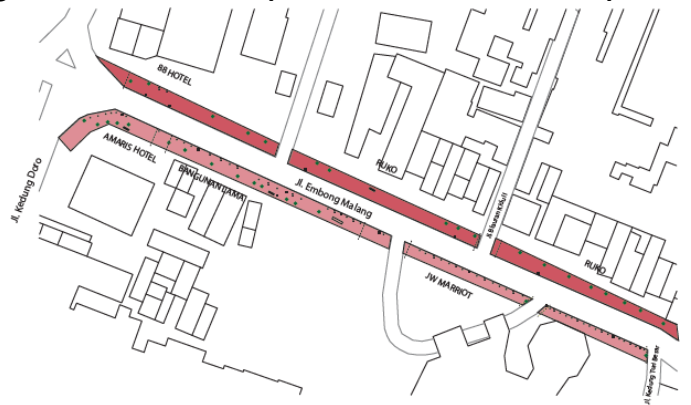

Gambar 41. Peta tingkat pengguna pedestrian hari libur sore segmen 3 (Sumber: Analisa penulis, 2019)

Kegiatan pedestrian di segmen 3 hampir sama dengan segmen 2 dengan tingkat dan kegiatan pengguna yang hampir sama.

\section{Pedestrian Utara}

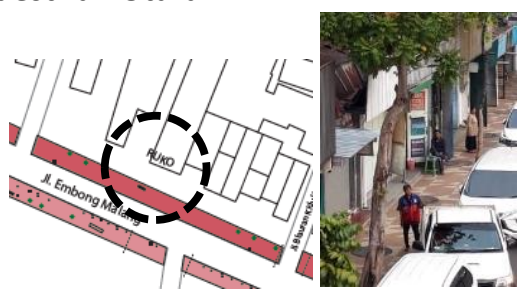

Gambar 42. Kegiatan di pedestrian utara (Sumber: Analisa penulis, 2019)

Tabel 25 menunjukkan tingkat pengguna pedestrian utara yaitu:

Tabel 25. Tingkat Pengguna Pedestrian Utara

\begin{tabular}{lll}
\hline Kawasan & $\begin{array}{l}\text { Tingkat } \\
\text { Penguna }\end{array}$ & Jenis Aktivitas \\
\hline Pertokoan & Ramai & Kegiatan jual beli \\
\hline Hotel & Ramai & Lalu lintas pejalan kaki \\
\hline
\end{tabular}

\section{Pedestrian Selatan}

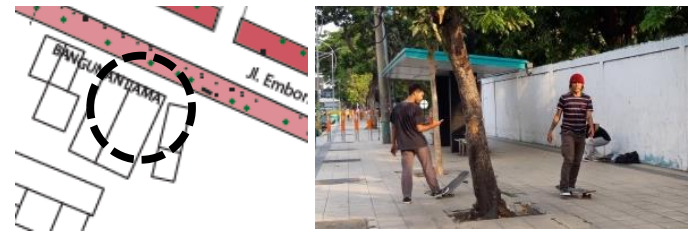

Gambar 43. Kegiatan di pedestrian selatan (Sumber: Analisa penulis, 2019)

Tabel 26 menunjukkan tingkat pengguna pedestrian utara yaitu:

Tabel 26. Tingkat Pengguna Pedestrian Selatan

\begin{tabular}{lll}
\hline Kawasan & $\begin{array}{l}\text { Tingkat } \\
\text { Penguna }\end{array}$ & Jenis Aktivitas \\
\hline Hotel & Sedang & Lalu lintas pejalan kaki \\
\hline Halte & Sedang & Skateboard \\
\hline
\end{tabular}

\section{KESIMPULAN}

Berdasarkan data observasi koridor Pedestrian Embong Malang, maka lokasi amatan dibagi menjadi dua bagian pedestrian berdasarkan posisinya yaitu pedestrian utara dan selatan dengan lebar masing 3 dan 7 meter dengan fasilitas sesuai tabel 27:

Tabel 27. Fasilitas Pedestrian Utara dan Selatan

\begin{tabular}{lcc}
\hline \multicolumn{1}{c}{ Fasilitas } & $\begin{array}{c}\text { Pedestrian } \\
\text { Utara }\end{array}$ & $\begin{array}{c}\text { Pedestrian } \\
\text { Selatan }\end{array}$ \\
\hline Vegetasi & Ada & Ada \\
\hline Lampu Taman & Ada & Ada \\
\hline Tempat Sampah & Ada & Ada \\
\hline Tempat duduk & Ada & Ada \\
\hline Portal pedestrian & Ada & Ada \\
\hline Zebracross & Ada & Ada \\
\hline Jembatan & Ada & Ada \\
$\begin{array}{l}\text { Penyebrangan } \\
\text { Orang }\end{array}$ & & \\
\hline Guiding Block & Ada & \\
\hline
\end{tabular}




\begin{tabular}{lcc}
\hline Fasilitas & $\begin{array}{c}\text { Pedestrian } \\
\text { Utara }\end{array}$ & $\begin{array}{c}\text { Pedestrian } \\
\text { Selatan }\end{array}$ \\
\hline $\begin{array}{l}\text { Pembatas } \\
\text { Pedestrian }\end{array}$ & Ada \\
\hline Halte & Ada \\
\hline Toilet Portable & Ada \\
\hline
\end{tabular}

Sedangkan terdapat perbedaan tingkat pengguna berdasarkan waktu. Tabel 28 dan 29 menunjukkan perbandingan tingkat pengguna pedestrian:

Tabel 28. Perbandingan Penggunaan Pedestrian Utara Berdasarkan Waktunya

\begin{tabular}{lllll}
\hline & $\begin{array}{l}\text { Kerja/ } \\
\text { Siang }\end{array}$ & $\begin{array}{l}\text { Kerja/ } \\
\text { Sore }\end{array}$ & $\begin{array}{l}\text { Libur/ } \\
\text { Siang }\end{array}$ & $\begin{array}{l}\text { Libur/ } \\
\text { Sore }\end{array}$ \\
\hline Pertokoan & Sedang & Ramai & Sedang & Ramai \\
\hline Parkiran & Sedang & Ramai & Sedang & Ramai \\
\hline Hotel & Sepi & Sedang & Sedang & Ramai \\
\hline
\end{tabular}

Pedestrian utara cenderung stabil dan berfokus pada area pertokoan dengan kegiatan didominasi kegiatan perdagangan dan jasa serta lalu lintas pengguna jalan menuju hunian warga.

Tabel 28. Perbandingan Penggunaan Pedestrian Selatan Berdasarkan Waktunya

\begin{tabular}{lllll} 
& $\begin{array}{l}\text { Kerja/ } \\
\text { Siang }\end{array}$ & $\begin{array}{l}\text { Kerja/ } \\
\text { Sore }\end{array}$ & $\begin{array}{l}\text { Libur/ } \\
\text { Siang }\end{array}$ & $\begin{array}{l}\text { Libur/ } \\
\text { Sore }\end{array}$ \\
\hline $\begin{array}{l}\text { Tunjungan } \\
\text { Plaza }\end{array}$ & Sedang & Ramai & Ramai & Ramai \\
\hline $\begin{array}{l}\text { Pertokoan } \\
\text { Konstruksi } \\
\text { Bangunan }\end{array}$ & Sedang & Ramai & Ramai & Ramai \\
\hline Bank & Sepi & Sedang & Sedang & Sedang \\
\hline Halte & Sepi & Ramai & Ramai & Sedang \\
\hline Hotel & Sepi & Sedang & Sedang & Sedang \\
\hline
\end{tabular}

Pada pedestrian selatan tingkat pengguna berfokus ke Tunjungan Plaza dan area pertokoan, sedangkan area hotel cenderung sepi pada kedua pedestrian.

Tingkat pengguna jalan lebih tinggi pada hari libur dan periode waktu sore hari. Berdasarkan hasil uraian di atas dapat disimpulkan faktor yang mempengaruhi tingkat pengguna pedestrian:

1. Waktu penggunaan pedestrian

2. Lingkungan di area pedestrian

3. Dimensi dan fasilitas pedestrian

\section{DAFTAR PUSTAKA}

Adhitama, Muhammad. (2012). Faktor Penentu Setting Fisik Dalam Beraktifitas Di Ruang Terbuka Publik "Studi Kasus Alun - Alun Merdeka Kota Malang". Universitas Brawijaya.

Dharmawan, Doddy. (2004). Mengamati Peran Pedestrian dalam Kehidupan Sosial Ekonomi Masyarakat Studi Kasus Sudirman-Thamrin
Jakarta. Artikel Jurnal IImiah Arsitektur NALARs. Volume 3 Nomor 1 Edisi Januari 2004 Universitas Muhammadiyah Jakarta

Iswanto, Danoe (2006) Pengaruh Elemen Elemen Pelengkap Jalur Pedestrian Terhadap Kenyamanan Pejalan Kaki, ENCLOSURE Volume 5 No. 1, Jurnal Ilmiah Perancangan Kota dan Permukiman,

Kostof, Spiro. (1992). The City Shape: Urban Patterns and Meanings Through History. London: Thames and Hudson.

Mukhtar. (2013). Metode Penelitian Deskriftif Kualitatif. Jakarta : GP Press Group.

Nasution, Niki. Widiyastuti, Dyah. Purwohandoyo, Joni. (2016). Analisis Penilaian Fasilitas Pedestrian Di Kawasan Perkotaan (Kasus: Jalan Malioboro - Jalan Margo Mulyo, Yogyakarta).

Nawawi, H, Martini M. (1996). Penelitian Terapan, Gajah Mada University Press, Yogyakarta

Panduri, Ronadan. Suwandono, Djoko. (2015). Perilaku Masyarakat Dalam Penggunaan Jalur Pedestrian Di Koridor Jalan Prof. $H$. Soedarto, S.H. Universitas Diponegoro

Rapoport, Amos. (1977). Human Aspect of Urban Form, Towad a Men Environmental Approach to Urban Form and Design. New York : Pergarmont Press

Sanjaya, Rian. Soedarsono. Mudiyono, Rachmat. (2017) Analisis Fungsi Dan Kenyamanan Jalur Pedestrian Kawasan Di Kota Pangkalan Bun. Universitas Islam Sultan Agung Semarang

Shirvani, Hamid, (1985). The Urban Design Process. New York : Van Nostrand Reinhold Company

Susanti, Wiwik D. (2014). Faktor-Faktor Yang Mempengaruhi Pemanfaatan Ruang Terbuka Publik. Universitas Pembangunan Nasional "Veteran" Jawa Timur.

Pemerintah Indonesia. (2006). Peraturan Pemerintah Republik Indonesia Nomor 34 Tahun 2006 Tentang Jalan. Lembaran RI Tahun 2006, diakses dari

https://pelayanan.jakarta.go.id/download/regul asi/peraturan-pemerintah-nomor-34-tahun-

2006-tentang-jalan.pdf, diakses pada 8 Januari 2019.

Pemerintah Kota Surabaya. (2003). Peraturan Daerah Kota Surabaya Nomor 07 Tahun 2003 Tentang Perubahan Atas Peraturan Daerah Kotamadya Daerah Tingkat li Surabaya Nomor 14 Tahun 1999 Tentang Retribusi Penggantian Biaya Cetak Peta, diakses dari https://jdih.surabaya.go.id/pdfdoc/perda_50.pd f diakses pada 8 Januari 2019.

Wibawa, Samodra. (1994). Kebijakan Publik, Proses dan Analisis. Jakarta : Intermedia. 